Acta Universitatis Wratislaviensis No 3998

Anglica Wratislaviensia LVIII, Wrocław 2020

https://doi.org/10.19195/0301-7966.58.4

Jeremy Pomeroy

ORCID: 0000-0003-1380-7877

Adam Mickiewicz University

jeremy.pomeroy@amu.edu.pl

\title{
The Depiction and Ethic of Pride in the Work of Countee Cullen
}

\begin{abstract}
Countee Cullen's literary oeuvre emerged in a cultural context wherein Harlemite leaders took pride in an emerging intellectual and literary vanguard. Interestingly, Cullen's work foregrounds many of the negative aspects of both personal and group pride. Pride for Cullen is typically unnatural, a compensatory excrescence to be shed or managed; this corresponds more closely to a Christian than to a pagan ethos of pride. As regards pride in one's group identity, although readings of Cullen in terms of gay pride would be anachronistic, he deliberately treats the topic of racial pride-particularly in his novel One Way to Heaven, wherein pride figures a structurally integral leitmotif.
\end{abstract}

Keywords: Countee Cullen, One Way to Heaven, pride, Christianity, paganity

\section{Introduction}

The Harlem Renaissance of the 1920s represented a milestone not only in the saga of American literary history but also, and more particularly, in that of AfricanAmerican assertions of equal cultural and intellectual competence. The final decades of the 19th century had "witnessed the failure of racial emancipation initiated during the Civil War [as a result of the Jim Crow era]" and seen "[e]conomic and legal emasculation ... reinforced with physical violence primarily in the form of the lynching practice" (Pochmara 18). The ensuing Great Migration northward saw many leave the south in favour of such less repressive milieus as New York's Harlem; although conditions were far from perfect, in the comparative absence of an immediate existential threat the following generation began articulating the unabashed confidence of the "New Negro".

One potential asset clearly recognized by Harlemite leaders in their attempts to positively transform public attitudes and preconceptions towards African-Americans was Harlem's thriving cultural scene. Demands for civil rights and human 
respect could naturally be bolstered by foregrounding incontrovertible examples of the intellectual, cultural and artistic capabilities of eloquent, educated and talented black Americans. This strategy was both deliberate and conscious, as articulated in W. E. B. Du Bois' notion of a "talented tenth": a vanguard African-American intelligentsia. This elite was to have shed any vestigial feelings of inferiority resultant from past oppressions; recognition of their accomplishments would both inspire other African-Americans, and also debunk any racist preconceptions of white superiority. The New Negro represented an enthusiastic affirmation of one's black identity. Du Bois's Credo (1904) stated stridently that he believed in "pride of race and lineage and self; in pride of lineage so great as to despise no man's father; in pride of race so chivalrous as to neither offer bastardy to the weak nor beg wedlock of the strong" (Du Bois 3). Alain Locke, another intellectual "midwife" of the Harlem Renaissance, spoke of "a "race pride," "race genius," and the "race-gift", which were to be cultivated through "developing a distinctive culture, a hybrid of African and African American elements" (Buck 115).

Amidst such a cultural context, the precocious Countee Cullen would emerge as one of the early Harlem Renaissance's most celebrated and promising poets. Although by the mid-20th century his oeuvre was frequently viewed as having been "insufficiently politically radicalised", "safe [and] too reliant on "European" sources" (Molesworth 68), in the 1920s this same aesthetic stance made Cullen's work broadly accessible beyond the Harlemite literary milieu. Cullen would predictably have become an object of "race pride" for those promulgating the New Negro. On the other hand, such exemplarity was dependent upon obscuring certain facets of Cullen's personality (his bisexuality or homosexuality) and was often controverted by the poet's own insistence on being considered preeminently "a poet" rather than "a black poet". Contemporarily, assertions of "black pride" and "gay pride" have acquired positive connotations of self- and group-affirmation. In Cullen's lexicon, however, one finds the phenomenology of pride to be extremely ambivalent.

Even a cursory look reveals that pride is a leitmotif and singular preoccupation for Cullen. In his first poetry volume, Color (1925), lexical instances of pride include: "the soul of Africa / [...] winged with arrogance" (Early, "A Song of Praise" 80); "A Brown Girl Dead" whose mother has had her arrayed for her funeral so resplendently that she'd "proud[ly] ... dance and sing / [t]o see herself tonight" (ibid. 82); "Black Magdalens" who "wrap their wounds in pride" (84); and Cullen remembering himself working as an "Atlantic City Waiter" "half of [whose] pride [was] disavowed / in vain" (ibid. 85) In particular, an early epitaph "For Himself" underscores the centrality of this preoccupation, with Cullen noting that "Folly and Pride and Love" will lie buried with him (121). This list is only partial, and Cullen's engagement with pride is not limited to Color but continues throughout his literary career. The following section seeks to characterize the general attitude towards

${ }^{1}$ Unless otherwise indicated, all Cullen citations are from the anthology My Soul's High Song. 
pride exhibited in Cullen's poetry, including in his children's book The Lost Zoo; the third section then considers pride in belonging to groups specifically. In the latter case, particular emphasis is paid to Cullen's sole novel, One Way to Heaven.

\section{The Psychodynamics and Phenomenology of Pride in Cullen's Work}

As regards a context for considering the values expressed in Cullen's work, a logical recourse is the poet's self-penned bio for the anthology Caroling Dusk (1927), wherein Cullen describes his chief problem as that of "reconciling a Christian upbringing with a pagan inclination" (179-180). This recurrent tension, whereby Christian renunciation and humility is counterpoised against less restrained, more chthonic impulses associated both with classical Greece and Africa, is a sustained and deliberate feature of Cullen's literary expression; it thereby provides a point of departure for examining Cullen's valorization of pride. As regards Christian theology, pride conventionally represents one of the seven deadly sins, with the Lord "detest[ing] all the proud of heart" (Proverbs 16:5). In a pagan context, on the other hand, pride itself is not intrinsically negative, as it may simply imply "high, merited self-esteem" (Achtenberg 102). Hubris, excessive pride, however, risks nemesis and comeuppance. In Cullen's work one might anticipate drawing upon both traditions.

That being said, in light of Cullen's stated attempt to reconcile the pagan and Christian, what is particularly salient is a comparative absence of positive depictions of pride. A rare exception is "Love's Way" (Copper Sun, 1927), wherein Cullen claims "[r]enunciatory never was the thorn / [t]o crown love with, but prodigal and proud!": a pagan, aristocratic view of pride, implying generosity by a lover "too proud / [t]o owe you one caress". Nevertheless, even in this case, a plausible reading can view pride as being ultimately redeemed through a soteriology of love, which "rehabilitates unto the end" (161). This perspective is also later contradicted in The Black Christ and Other Poems (1929), wherein Cullen refers nostalgically to "some poor poet in his pride / [a]nd poverty" having naively written that "Love is enough". Here, Cullen's rhetoric ultimately confirms the contrary:

... pride I found can blind our eyes,

And poverty is worse than pride.

Love's breed from both is a nest of lies;

And singer of sweet songs, you lied (185)

Pride in this case may pervert love, and thusly should be resisted rather than integrated into the personality. By this point in Cullen's work, the mortification of proud flesh by death becomes prevalent: he invokes "[a] pride which has its genesis in dust" (187) and claims the heart "being proud ... strikes its hours in pain" (195). The apparent tropism tends ever more towards the moralistic, Christian perspective. 
Cullen's preoccupation with pride has not failed to attract critical attention. In one particularly cogent analysis, Jean Wagner analyses the treatment of "Pride as Solace" on the basis of several Cullen poems. Such solace turns out to be only a temporary, illusory analgesic. Wagner firstly notes that fierce manifestations of pride often correlate with contemplations of defiant suicide, as in "Harsh World That Lashest Me" or "The Black Christ" (300); if this be the case, prideful refusal of life is a response to powerlessness and shame. Pride is "the equivalent of an attitude carefully formulated to disguise an instinctive self contempt" (301). Pride is thusly a form of self-disguise or self-deception; as such, it is not natural or innate, but experientially occasioned. Wagner provides a very cogent close reading of a "Sonnet" from The Medea and Other Poems, noting the externality of the pride metaphors Cullen invokes: "[w]hether seen as leeches attached to his hands in order to hinder their movements or reins laid upon him as a constraint thwarting the spontaneity of his nature, pride, within Cullen's deepest being, is still a foreign element that has been deliberately imposed on his true personality" (301).

A late work, his children's book The Lost Zoo (1940), substantially corroborates Wagner's analysis of pride as the flip side of shame. As a collection of animal fables, the book also sees Cullen moralise directly. Cullen recounts the reasons why eight fantastic, extinct animals failed to embark on Noah's ark, two of which present moral fables related to pride. Perhaps unsurprisingly, the first invokes the archetypal figure of pride, the "Snake-That-Walked-Upon-His-Tail". Despite the immediate Miltonian connotations, Cullen's snake does not deceive or rebel, but merely succumbs to hubris. After observing humans walking, the snake feels "a failure, weak and faulty" (76); through ambition and willpower, however, he eventually sprouts feet, then "[w]axe[s] fat on praise and admiration, / [f]or[gets] his former lowly station" (77). Certain he can walk to the ark in time, the snake arrives too late. Cullen delivers an explicit moral: "too much pride and too much glory / Bring dismal climax to our story" (77). The connection between inferiority and pride is equally explicit in the story of the timorous Squilililigee:

... if perchance his pride were hurt

That merry flag [his tail] drooped in the dirt

Quite distressfully,

And tears as large and wet as those

You ever shed rolled down the nose

Of Squilililigee!

But he was fated from the start

To have a most unhappy heart,

Broken easily;

He never had an answer pert

For others when his pride was hurt-

Shy Squilililigee. (52) 
As with the snake, inferiority both creates and is masked by pride. Furthermore, the Squilililigee's decision to forego the ark and drown is consistent with Wagner's having noted the correspondence between pride and thoughts of suicide. What might be noted from the children's book is that Cullen's moralistic attitude is deliberate, articulate and, incidentally, similar to modern psychology whereby pride is considered a "self-inflating ... or as [an] other-distancing emotion" (van Osch, Zeelenberg and Breugelmans 1).

\section{Group Identity and Pride in Cullen's One Way to Heaven}

"Gay Pride" as such does not appear to figure in Cullen's work, presumably because "the binary of homo-heterosexuality did not yet govern most people's perception of sexual relationships during the 1920s" (Schwarz 3). Cullen instead invokes the "Greek-Whitmanesque idiolect to render his relationships with men" (Pochmara 80); rather than any identarian pride, therefore, one finds only depictions of pride in having secured the attentions of particular lovers. In particular, in what is arguably Cullen's most uncoded homosexual poem, one finds a rare case of pride with positive connotations:

Locked arm in arm they cross the way,

The black boy and the white,

The golden splendor of the day,

The sable pride of night. ("Tableau" 86)

That being said, the terms "golden splendor" and "sable pride" clearly syntactically correspond to "day/white" and "black/night". The poem does support a queer reading, but Cullen expresses no explicit pride in any homosexual identity. Cullen's poetic treatment of pride in love therefore reads consistently, regardless of whether the lover is coded male or female (with many of Cullen's love poems being studiously non-gendered in their choice of "you"): the poetic subject may feel pride in a lover's attentions, and offers reflections upon pride's (often deleterious) effects upon love, intimacy and attraction.

In the case of racial pride, however, the situation is radically different. Cullen explicitly engages with racial pride. Consistent with the individual psychodynamics of pride observed by Wagner, racial pride is presented as an inverse or corollary to those feelings of shame, powerlessness, and/or inferiority induced by racial discrimination. In "The Black Christ", pride is "in the air [Jim] breathe[s]"; he fears "[s]ome man contemptuous of [his] race / [w]ill strike [him] down for being black", leading to his retaliation. This, Jim correctly predicts, would lead to his being lynched:

... but not before

I send some pale ambassador 
Hot footing it to hell to say

A proud black man is on his way. (214)

Jim's mother, although a devout Christian, also displays pride, boasting that "[she] and the dirt see just as high /[a]s any [rich, white] lady cantering by (210); the mother speaks of "[Jim's] father, lean and black, / [p]a[ying] court to [her] with all the knack / [o]f any dandy in the town":

So spake my mother, and her pride

For one small minute in its tide

Bore all my bitterness away. (211)

After Jim's white girlfriend is called a slut by a white man who also strikes him, Jim does retaliate and kills the attacker. Predictably, he is hunted down, and only escapes lynching via the deus-ex-machine of a miracle: Christ assumes Jim's place as his doppelgänger. One would stress that pride is not the primary theme or moral of the poem, yet a reading in terms of pride remains possible. When the mother sees the Black Christ (whom she takes to be her son), she is depicted with humility rather than pride: "[h]er pain, a vision so complete / ... sent her humbly to his feet" (212). This tropism from pride to humility is consistent with a soteriological reading.

The most overt treatment of racial pride, however, is found in Cullen's only novel, One Way to Heaven. Furthermore, a strong argument can even be made that pride, in the widest sense, is an integral leitmotif of the book, which features two differing social milieus (working-class and elite Harlem) in its main plot and subplot. These are only tenuously connected via the somewhat frail device of the heroine Mattie working as Constancia Brandon's maid; thematically, however, pride figures prominently in both narrative threads, and potentially lends the novel a greater structural integrity than it might appear to possess at first glance. The lexicon of pride is present in the first depiction of the novel's protagonist, one-armed con-man Sam Lucas:

[Sam] had a fine, intelligent-looking face which he could never justify with his mind; a slightly elongated head with high-mounting cheek-bones, and sinking jaws, which gave him a hungry, somewhat acidulous look though his stomach might be full and satisfied; he often wondered why his mouth should be so wide and his lips so thin; he sometimes pursed his mouth up when he laughed, ashamed of its reckless expanse whenever he happened to let himself go; but he was proud of his strong, even white teeth, wedged like unpunctured dice in their firm red sockets. He had a woman's conceit for his eyes and his skin. The former were a deep electric brown, and nothing could be blacker or smoother than his skin, marred only where a long knife-wound in healing had left a sweeping streak of tan on one cheek ... (352)

Pride continues to play a role throughout the novel's inciting incident, whereby Sam runs a practised con: feigning repentance in a church revival service, he renounces a life of gambling, then profits from the charity of the congregation. $\mathrm{He}$ has his customary props, playing cards and a razor. As he enters the church and awaits his moment, the lexicon of pride continues unabated: "[t]onight's setting 
filled him with pride; the immensity of the place, the number of the people, appalled and fascinated Sam" (354). In this case, however, Sam is recognized by the travelling preacher, who has been taken in by the scheme once before. Nevertheless, although appalled at the trickster, Clarence Jackson does not denounce Sam, and his reason for not doing so stems from his having felt "personally humiliated" at this inability to convert a recalcitrant young Mattie (362) - despite his having personally gone down from the pulpit to appeal to the girl. Mattie, touched by Sam's false conversion, relents, and the preacher allows the deception; this is the beginning of Sam and Mattie's ill-starred romance. Mattie keeps the playing cards and razor, treating them as holy relics, while Sam feels a "half-regretful pride that such store should be set by his ancient, fraudulent possessions" (379).

As is foreshadowed in the initial description of the con man, Sam's pride, defiance and confidence are partially an act. This is metaphorically symbolized by his empty sleeve. The familiar tropism from shame and insecurity to arrogance and pride recurs in Sam's psychology, particularly in the context of religious ceremonies. When attending church with Mattie, he feels "mean and ashamed" (395) at his duplicitousness, feigning himself a believer; before being socially pressured into taking communion, he particularly feels "his own unworthiness", yet this dissipates into "his former arrogance and scorn" (399-401) once Sam realises the Body of Christ tastes like ordinary bread. This psychology is paralleled in a second religious rite, that of their marriage, which is held in the house of Constancia, Mattie's fond employer. Prior to the wedding rite, Sam feels "great shame" at not having brought a ring, as well as "small and cheap" when the minister speaks of Sam endowing upon his bride all his worldly goods - particularly in the company of the well-todo Harlem literati and intelligentsia invited by Constancia (426). Immediately after the union is proclaimed by the minister, however, Sam becomes "[f]orgetful and scornful of his surroundings" (ibid). Once they are wed, Mattie "pridefully" brings her husband the same breakfast as Dr. and Mrs. Brandon typically have, to his consternation (437); he, in turn, basks in confidence at being seen with his new wife:

As they had taken their seats, one coffee-coloured rowdy, overcome by the cherry dress and Mattie's piquant black face, had exclaimed, "Must be recess up in heaven; they's let an angel out." And Same had not been offended, but had grown cocky like a rooster, proud of the envious eyes upon him.

... Finally she had gone [out dancing] with him, and how she had danced! ... He had seen more than one man ... pause and lose his step looking at Mattie.... And what a tremendous joy it had been for them for them to scorn a taxi and to walk home after the dance, his arm supporting her, infused with the strength of two arms now by the full tide of possession. (44)

Given Cullen's poetic treatment of pride and love, this does not bode particularly well. Interestingly, given the reverend's complicity in the couple's first getting together, the deterioration largely occurs over religion; once more, this may be interpreted in terms of pride and shame. When Sam and Mattie join the congregation, the two are "such delightful specimens of handsome blackness that the kindly feelings of the audience went out to them in great waves of sympathy and 
pride" (396). Sam, however, predictably, backslides after a month, refusing to return to church. Mattie cannot accept this, as she "[can] hardly speak for shame when [fellow churchgoers] inquir[e] about Sam" with "slow Christian smiles that [are] half sympathy and half derision" (498); at the same time, she remains "an acquisition toward whom the church pointed with pride, even if with pity, on account of her backsliding husband" (500-501). She eventually tricks Sam into attending, at which point she ambushes him with a public appeal to reconvert. Sam barges out with "hot shame": the inverse of pride. Notably, Cullen depicts Mattie in an explicitly parallel position of impotence and defeat to that of Reverend Jackson earlier: "Mattie [stood] defeated as a certain minister had done" (501).

Relationships, however, are only one aspect of pride in One Way to Heaven; to examine pride as an integrating structural motif, one must turn to the subplot, which invokes the more specific theme of racial pride. As noted, the novel's subplot centres around those soirees organized and presided over by Mrs. Constancia Brandon. Given Cullen's own reluctance to be limited to a racial identity as a "black" or "Negro" writer, it is also extremely easy to view Constancia as an authorial porteparole. Her events, frequented by the Harlemite literati, afford Cullen a context for expressing ideas about literature and race: e.g. the fete to celebrate the publishing of Herbert Newell's novel. One learns that Newell's two main characters are a prostitute and stevedore, leading to his being criticized for depicting less-than-ideal African-American characters. One character, Mrs. de Peyster Johnson-(more on her presently) - regretfully admits she will buy the book "out of pride of race, although ... [she] shall hardly like it [on account of the subject matter]". Constancia reassures Herbert, telling him to write whatever he wants, commenting:

“... That's race pride with a vengeance for you, and self-criticism that isn't worth a penny."

"I wish they were all like you, Constancia," Herbert assured her ... Good god! I wasn't writing a history about the Negro. I was trying to write a novel." (470)

It is very tempting to see this as a self-aware novelist anticipating criticisms of his own roguish protagonist. Constancia's attitude towards her race admits autocriticism, even if to others this might not seem timely in light of the perceived imperative for a common front. Constancia is ultimately a universalist: she "often think[s] the Negro is God Almighty's one mistake, but as [she looks about her] at white people, [she is] forced to say so are we all" (471).

Although other members of Constancia's social circle are less roundly sketched, the flatter characters suffice as a vehicle for Cullen to critique racial pride. A particularly biting portrayal occurs in the case of the aforementioned Mrs. de Peyster Johnson, who organises the Back-to-Africa society and "bitterly" accuses Constancia of being "totally devoid of race pride" (479). On the one hand, one can certainly sympathize with de Peyster Johnson's "find[ing] more to be proud of [in that her ancestry can be traced to a slave ship] than if they had come over on the Mayflower"; ultimately, however, her justification is that among the slaves there were 
royalty (448). In a particularly ironic decision, it is revealed that she declined to marry the man she truly loved because " $[t]$ here is something basically wrong ... in a Negro who is light-complexioned, sandy haired, and named Thomas Asquith", having opted instead for her a man who is "soot-colored" but lacks both her literary interests and - most ironically — her "sympathy for the New Negro" (448-449). Given Cullen's penchant for such writers as John Keats and Edna St. Vincent Millay, that as a schoolteacher de Peyster Johnson avoids teaching any white writers until reprimanded by her superiors can hardly find favour. Cullen furthermore observes that as a teacher Mrs. De Peyster Johnson "[s]o strongly ... emphasize[d] racial purity that the darker children were on the verge of becoming little prigs and openly snubbing their lighter-complexioned comrades" (450) — as she herself has done when choosing a husband.

An argument for a thematic unity of the novel can be made on the basis that all the various depictions of pride (in love, in/against religion, and in race) converge in the protagonist, Sam. After his having been shamed by Mattie in church, the two become estranged, and he takes up with a lover-unaware that Mattie is pregnant. One sees both characters are flawed, for Sam becomes actually and Mattie potentially violent. In the latter case, "[p]roud and sorrowing, bolstered up only by her faith and by the sudden realization of life growing within her" but "too proud to speak to same of [her pregnancy] which was as much his as hers", Mattie takes a hatchet and goes to confront Sam's mistress. Mattie is unable to complete the assault. Having learned what she intended to do, Sam, on the other hand, does drunkenly stab their bed (with the razor Mattie venerates), only failing to kill his wife as she happens not to be lying there. In the aftermath, Mattie defiantly reveals her pregnancy, and that he would have killed not only her but their unborn child. At this point, Sam swells with pride at the fact that he will have a black son (never even contemplating, incidentally, that Mattie might give birth to a daughter).

Sam's pride in the baby's skin colour is repeatedly foregrounded. What briefly reconciles the two is Sam's thought of a "little black baby, like me and you" (512), yet Cullen makes short work of this rapprochement. The following chapter skips abruptly to after Mattie's miscarriage, moralisingly concluding that "[p]ride wields a bitter tongue, but love eats bitter bread" (514). As one learns from Mattie's reminiscences in bed, Sam does not appear to have contemplated the child in terms of love, but rather in terms of compensatory pride. Still in love with the reprobate, she thinks:

with bitterness of the dreams she had watched grow in Sam's heart at the thought of his son. It had amused him highly to think how black the child would be, coming from them, the utter distillation of race. It had been fun to see Sam build and demolish his great air castles, to hear him choose and reject the work his son was to do; no rounder like himself - not his boy; he would be a doctor or a lawyer or a teacher, something fine. "And when he's rich and great," Sam had said over and over again with his son's destiny in his yes, "as black as he'll be, nobody will be able to say it's on account of his white blood, because there ain't a drop between you and me." (514) 
With the baby having miscarried, Sam's lack of empathy is underscored both by his callous pronouncement that she is "[n]ot even able to born a baby" and also his absence at the funeral (having taken up again with his mistress). The money he sends Mattie refuses "proudly", although Cullen describes the "low suffering voice of affection drowning the strident voice of pride" (514). For a Christian writer, the novel ends on a surprisingly ambiguous note, with Sam brought low - and brought back to his wife - by pneumonia. In his final, "sweetest, kindest trick of all" (529), Sam pretends to hear celestial music, relishing the assurance that his widow "[will] never get the benefit of her beauty ... and go off with another man" but "[will] tell over and over how he had saved her" (529).

\section{Pride as a Universal}

Only in the rarest of cases is pride even slightly positive for Cullen; overwhelmingly present is a profoundly Christian conception of a vice inviting chastisement. Yet the vice of pride is not "natural" in the sense of inborn, but results from compensation for feelings of inferiority. Whether this be personal pride or pride in one's racial group, the depiction is consistently negative. Despite being one of the writers in whom the Harlem milieu could take pride, Cullen cautions against pride generally and "race pride" in particular.

On the other hand, it would be overhasty to equate Cullen's criticism of racial pride with any criticism of blackness as such. Cullen is not without an unambiguously positive vocabulary to describe blackness when he wishes to do so; he simply tends to eschew the lexicon of pride in such instances. In a poem dedicated to Haitian revolutionaries, Cullen unequivocally praises the "sable glory"; elsewhere, he celebrates eponymous "Black Majesty" (200). Cullen's critique of "race pride" therefore reserves space for celebrations of blackness. Furthermore, in One Way to Heaven negative actions and emotions are circumspectly universalized, precluding any reading in terms of racial characteristics. When Mattie appears ready to kill her rival, her psychological state is studiously framed as a human universal: "[t]he primitive woman, she whose skin is neither white nor black, look[s]out of Mattie's blazing eyes" (508). Cullen's morals are, in short directed to Every(hu)man:

Let no man be so proud

And confident,

To think he is allowed

A little tent

Pitched in a meadow

Of sun and shadow

All his little own. (242) 


\section{References}

Achtenberg, D. 2002. Cognition of Value in Aristotle's Poetics. Albany: State U of New York P. Buck, C. 2005. Studies in the Bábi and Bahá'í religions. Los Angeles: Kalimát Press.

Cullen, C. 1993. Caroling Dusk: An Anthology of Verse by Black Poets. New York: Citadel Press. Cullen, C. and C. Cat. 1968. The Lost Zoo. Chicago: Follett Publishing Company.

Du Bois, W. E. B. 1920. Darkwater: Voices from within the Veil. New York: Harcourt, Brace and Company.

Early, G. (ed.). 1991. My Soul's High Song: The Collected Writings of Countee Cullen, Voice of the Harlem Renaissance. New York: Doubleday.

Molesworth, C. 2012. "Countee Cullen's Reputation.” Transition, Blending Borders 107. 67-77.

Osch, Y. van, M. Zeelenberg and S. M. Breugelmans 2018. "The self and others in the experience of pride." Cognition and Emotion 32(2). 404-13.

Pochmara, A. 2011. The Making of the New Negro. Amsterdam: Amsterdam UP.

Schwarz, C. 2003. Gay Voices of the Harlem Renaissance. Bloomington: Indiana UP.

Wagner, J. 1973. Black Poets of the United States from Paul Lawrence Dunbar to Langston Hughes.

Chicago: U of Illinois P. 